\title{
Blood Biochemical and Immunological Responses to Garlic Oil Administration in Growing Rabbits Diet
}

\author{
M. R. El-Gogary ${ }^{1}$, A. M. Mansour ${ }^{1}$ \& E. A. El-Said ${ }^{2}$ \\ ${ }^{1}$ Department of Poultry Production, Faculty of Agriculture, Mansoura University, Mansoura, Egypt \\ ${ }^{2}$ Department of Poultry Production, Faculty of Agriculture, Damietta University, Damietta, Egypt \\ Correspondence: M. R. El-Gogary, Department of Poultry Production, Faculty of Agriculture, Mansoura \\ University, Mansoura 35516, Egypt. E-mail: melgogary@mans.edu.eg
}

Received: October 9, 2017

Accepted: November 12, 2017

Online Published: December 15, 2017

doi:10.5539/jas.v10n1p217

URL: https://doi.org/10.5539/jas.v10n1p217

\begin{abstract}
The effect of dietary supplementation garlic oil on performance and blood parameters of New Zealand White rabbits has been studied. The garlic oil was added at graded levels of $0.0,0.25,0.5$ and $0.75 \mathrm{~g} / \mathrm{kg}$ for T1 (control), $\mathrm{T} 2, \mathrm{~T} 3$ and T4, respectively. A total of thirty six male rabbits, 7 weeks of age and with an initial weigh of $950 \mathrm{~g}$ were used. There were four treatments, each with three replicates $(n=3)$ in randomly divided design. The parameters investigated were growth performance, carcass yield, glucose, plasma lipids profile, immunoglobulin's G (IgG, IgA and IgM), antioxidant status and testosterone hormone. The results showed that feeding diet supplemented with garlic oil had insignificant effect on body weight, body weight gain, feed intake, feed conversion ratio, triglycerides, cholesterol, LDL and HDL. Rabbits fed the $0.5 \mathrm{~g} / \mathrm{kg}$ garlic oil diet had significantly increased IgG level, hence improved immune responses and Testosterone hormone of rabbits. The colony forming units of coliform bacteria showed a significantly lower number compared with control. The present results indicate that supplemented of garlic oil at $0.5 \mathrm{~g} / \mathrm{kg}$ of diet has a positive effect on HDL, immunoglobulin's G, antioxidant status and testosterone hormone in addition to its antibacterial effect.
\end{abstract}

Keywords: garlic oil, blood parameters, immunity, rabbits

\section{Introduction}

The utilization of anti-infection agents, as development parameters, in animal and poultry diets has been prevented because their residuals in animals' tissues and induction of microorganism antibiotic resistants (Roe \& Pillai, 2003; Saleha et al., 2009). Thus, scientists are looking for safe choices: for example, phytobiotics, non-antibiotic prophylactics, and natural products for improving performance of animals. Several studies have been investigated the beneficial effects of garlic on human and animals, as antimicrobial, antiviral, antiparasitic and antioxidant properties (Ankri \& Mirelman, 1999; Corzo-Martinez et al., 2007).

The majority of essential oils involves mixtures of phenolics and polyphenols, terpenoids, saponines, quinine, esters, flavone, flavonoids, tannins, alkaloids and nonvoltiles residues; however their concentration is variable. These compounds have many benefical effects as antimicrobial, digestive system, enzyme stimulators antioxidants, anticoccidail and forimprove utilization of nutrients by enhancing digestion, absorption and liver function (Ziarlarimi et al., 2011). Garlic (Allium sativum) is known worldwide as spice and herbal medicine for preventing a variety of diseases ranging from infection to cardic diseases. Garlic supplement, as very rich aromatic essential content, to broiler chicks is fundamental because its strong stimulating effect on the immune system and its positive effects on digestion in birds (Demir et al., 2005). The benefits of garlic, for human, include reducing the total plasma cholesterol, blood pressure and platelet aggregation (Chan et al., 2013).

Garlic supplementation showed gross activity of caecum microflora (Abdel-Azeem \& Abdel-Reheem, 2006). The garlic extract has been reported to have a critical role as anti-bacterial agents against multi-drug resistant bacteria (Rana et al., 2011; Salih et al., 2016). Sasaki et al. (1999) found that garlic powder against Escherichia coli, Staphylococcus aureus, Salmonella enteritidis, which has been used to fight bacterial infection since it exhibits abroad antibiotic spectrum against some bacteria strains (Adeniyi et al., 2006). 
Therefore the present study was carried out to study the effects of different levels of garlic essential oil in the diet on growth performance, carcass yield, blood biochemical and immunological responses of growing NZW rabbits.

\section{Materials and Methods}

The present study was conducted at the rabbitry farm belonging to Agriculture Experimental Station, Poultry Production Farm, Faculty of Agriculture, Mansoura University, Egypt, during the period from March to May, 2016. Thirty six males, 7 week-old; New Zealand White rabbits (NZW) were randomly divided to four equal groups; each consisted of nine rabbits. The initial body weight of rabbits in all treatments $(954 \pm 19.5 \mathrm{~g})$. Each treatment was replicated three' times. The data of each replicate was pooled from three rabbits.

\subsection{Experimental Design}

Rabbits in T1 were fed on a commercial diet, whereas those in T2, T3 and T4 were fed on the commercial diet supplemented with garlic essential oil at levels of $0.25,0.5$, and $0.75 \mathrm{~g} / \mathrm{kg}$, respectively. The nutrients of the commercial diet is given in Table 1 . Rabbits were housed on one tier- battery cages, each measuring $50 \times 60 \mathrm{~cm}$; equipped with suitable feeders and nipple drinkers. The duration of experiment was 8 weeks (7-13 wk).

\subsection{Measurements}

The live body weight (LBW), body weight gain (BWG), feed intake (FI) and feed conversion ratio (FCR) were the criteria measured during the entire experimental period.

\subsection{Blood Parameters}

Before slaughtering and after complete bleeding, blood samples were individually collected from each rabbit in heparinized glass tubes. Blood glucose was immediately measured by one-touch blood glucose apparatus. Blood plasma was determined by separation by centrifugation at $3000 \mathrm{rpm}$ for 15 minutes. The plasma samples were stored at $-18{ }^{\circ} \mathrm{C}$ for determining the concentration of cholesterol (Chol.; Allain et al., 1974), triglycerides (TG; Fossati \& Prencipe, 1982), high density lipoprotein (HDL; Myers et al., 1994) and low density lipoprotein (LDL; Friedewald et al., 1972), total antioxidant capacity (TAC; Koracevi et al., 2001), malondialdehyde (MDA; Mihara \& Uohiyama, 1978). Testosterone assay was done by RIA, according to Sharp et al. (1977). Immunoglobulins (IgG, IgA and IgM) were determined by ElISA technique as reported by Bianchi et al. (1995).

Microbiological contents of the ceca from 3 rabbits/treatments were collected. The numbers of anaerobic bacteria, lactose enterobacteria as coliform bacteria, were counted on appropriate selective and nonselective agar plates.

\subsection{Analytical Methods}

Counting of Bacteria: Cecal contents from each treatment were at once transferred under a stream of $\mathrm{CO}_{2}$ into tubes containing $9 \mathrm{~mL}$ of a sterilized water. Total bacterial counts were determined on Nutrient Agar (Merck, 1994, 10233). Coliform bacteria were counted on MacConkey Agar (Merck, 1994, 5465) incubated aerobically for $24 \mathrm{~h}$ at $37^{\circ} \mathrm{C}$.

\subsection{Statistical Analysis}

One-way ANOVA was performed to analyze the data and means were separated using Duncan's multiple range test $(\alpha=0.05$; SAS, 1996). 
Table 1. Composition and calculated analysis of a commercial diet

\begin{tabular}{ll}
\hline Ingredients (\%) & Growing diet (7-14 weeks) \\
\hline Alfalfa hay & 20.00 \\
Wheat bran & 22.00 \\
Soy bean meal (44\% CP) & 20.00 \\
Fennel straw & 15.00 \\
Barley & 10.00 \\
Yellow corn & 10.00 \\
Limestone & 1.20 \\
Dicalcium phosphate & 1.00 \\
Salt & 0.50 \\
Vit. \& Min. Premix* & 0.30 \\
Calculated analyses (NRC, 1994) & \\
Digestible energy (kcal/kg) & 2512 \\
Crude protein \% & 18.02 \\
Crude fiber \% & 15.30 \\
Ether extract \% & 2.87 \\
Calcium \% & 1.30 \\
Non-phytate P \% & 0.71 \\
Lysine \% & 0.88 \\
Methionine \% & 0.23 \\
Meth. + Cyst. \% & 0.54 \\
\hline
\end{tabular}

Note. * Each 3 kg Vit. \& Min. Permix contains: Vit.A, 10,000,000 IU; Vit.D3, 1,000,000 IU; Vit.E, 10 g; Vit.K3, 1 g; Vit.B1, 1 g; Vit.B2, 4 g; Vit.B6, 1.5 g; Nicotinic acid, 20 g; Pantothenic acid, 10 g; Vit.B12, 10 mg; Biotin, $50 \mathrm{mg}$; Folic acid, $30 \mathrm{~g}$; Choline chloride, $50 \mathrm{~g}$; Fe, $30 \mathrm{~g}$; Mn, $40 \mathrm{~g}$; Cu, $3 \mathrm{~g}$, I, $0.45 \mathrm{~g}$; Zn, $45 \mathrm{~g}$ and Se, $0.1 \mathrm{~g}$.

\section{Results and Discussion}

\subsection{Growth Performance and Carcass Yield}

The effect of dietary supplementation of garlic essential oil on growth performance of rabbits during the experimental are shown in Table 2. There were no significant differences in LBW, BWG, FI and FCR during the starter and finisher periods due to garlic treatments. However, there is numerical increased in LBW and BWG of rabbits fed that $\mathrm{T} 3$ diet accompanied the best FCR during the whole experiment period (7-13 WK) although the difference lacked the significant level. These result are in agreement with other studies (Hossian et al., 2015; Alagawany et al., 2016) which indicated that the growth performance parameters of rabbits were not affected by garlic supplementation.

Table 2. Effect of garlic oil administration on productive performance of NZW rabbits at different ages

\begin{tabular}{|c|c|c|c|c|c|c|c|c|c|}
\hline \multirow{2}{*}{ Treat. } & \multicolumn{3}{|c|}{ LBW (Kg) } & \multicolumn{2}{|c|}{ BWG $(\mathrm{Kg})$} & \multicolumn{2}{|c|}{ FI (Kg) } & \multicolumn{2}{|c|}{ FCR } \\
\hline & 7 & 10 & 13 & $7-10$ & $7-13$ & $7-10$ & $7-13$ & $7-10$ & $7-13$ \\
\hline & ------ & 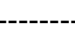 & 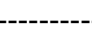 & 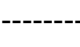 & $--W_{K}$ & ----- & 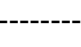 & ----- & -------י \\
\hline $\mathrm{T} 1$ & 0.96 & 1.62 & 2.13 & 0.66 & 1.18 & 1.96 & 4.33 & 2.96 & 3.67 \\
\hline $\mathrm{T} 2$ & 0.96 & 1.53 & 2.05 & 0.58 & 1.09 & 1.87 & 4.24 & 3.26 & 3.89 \\
\hline $\mathrm{T} 3$ & 0.96 & 1.60 & 2.20 & 0.63 & 1.23 & 1.85 & 4.24 & 3.01 & 3.48 \\
\hline $\mathrm{T} 4$ & 0.94 & 1.57 & 2.10 & 0.62 & 1.16 & 1.91 & 4.21 & 3.07 & 3.67 \\
\hline SEM & 0.02 & 0.04 & 0.059 & 0.04 & 0.06 & 0.02 & 0.07 & 0.22 & 0.20 \\
\hline Sig. & NS & NS & NS & NS & NS & NS & NS & NS & NS \\
\hline
\end{tabular}

Table 3 summarizes the effect of garlic oil supplementation on carcass characteristics at 13 weeks of age. Compared with the control diet, carcass weight and yield as well as liver, kidney, lungs and giblets were not significantly influenced by the garlic oil supplementation at the end of the experiment, however, the heart and 
testes were significantly higher in rabbits of garlic groups 0.5 and $0.75 \mathrm{~g} / \mathrm{kg}$ garlic oil (T3 and T4) than other groups. These results are in agreement with Onibi et al. (2009) who found that carcass and organ traits were not significantly affected by dietary garlic supplementation. Also, Raeesi et al. (2010) found that garlic supplementation at 1 or $3 \%$ level had no significant effects on carcass or digestive organs among trails in poultry.

Table 3. Effect of garlic oil administration on carcass characteristics of NZW rabbits at marketing age

\begin{tabular}{|c|c|c|c|c|c|c|c|c|}
\hline Treat. & LBW & Carcass & Liver & Heart & Kidney & Lungs & Giblets & Testes \\
\hline & \multicolumn{2}{|c|}{------------- kg ------------ } & \multicolumn{6}{|c|}{----------------------------------------------- g } \\
\hline $\mathrm{T} 1$ & 2.2 & 1.31 & 75.1 & $5.6^{\mathrm{b}}$ & 17.5 & 19.03 & 192.04 & $5.80^{\mathrm{b}}$ \\
\hline $\mathrm{T} 2$ & 2.3 & 1.31 & 68.1 & $6.3^{\mathrm{b}}$ & 18.3 & 15.53 & 176.27 & $6.53^{\mathrm{ab}}$ \\
\hline $\mathrm{T} 3$ & 2.2 & 1.26 & 87.4 & $8.7^{\mathrm{a}}$ & 18.4 & 14.20 & 216.07 & $7.80^{\mathrm{a}}$ \\
\hline $\mathrm{T} 4$ & 2.1 & 1.28 & 81.3 & $8.4^{\mathrm{a}}$ & 17.8 & 20.47 & 209.37 & $7.33^{\mathrm{a}}$ \\
\hline SEM & 0.10 & 0.07 & 8.39 & 0.63 & 1.03 & 2.99 & 15.67 & 0.43 \\
\hline Sig. & NS & NS & NS & $* *$ & NS & NS & NS & $* *$ \\
\hline
\end{tabular}

Note. a, b, c: Means in the same colum with different superscripts differ significantly $(\mathrm{P} \leq 0.05)$.

\subsection{Blood Parameters and Immunity Response of NZW Rabbits}

Results showed that blood glucose concentration of rabbits fed garlic supplemented diets was significantly lower than that of the control group. This may reflect a positive influence of garlic on carbohydrate metabolism via its effect on endocrine pancreas secretion, i.e. insulin. In this respect, Liu et al. (2005) have reported that garlic oil decreased blood glucose and improved the glycaemic control system in diabetic rats through increased insulin secretion and insulin sensitivity. This support our results a mechanism of action of garlic as a hypoglycemic agent was extensively discussed by (Belemkar et al., 2013) who found that possible inhibition of glucose transmit by garlic is due to the increased utilization of glucose by the gut wall which resulted in reduction of glucose transported into the serosal solution.

The effect of administration of different doses of garlic essential oil on blood glucose, cholesterol, triglycerides, HDL, LDL, IgG, IgM, IgA, TAC, MDA and testosterone concentrations are summarized in Table 4. There were no significant effect of garlic levels on plasma cholesterol, triglyceride, LDL in all group during the experimental period whereas, rabbit fed the $0.5 \mathrm{~g} / \mathrm{kg}$ garlic oil diet (T3) had significantly higher HDL level than other groups. These results are in agreement with previous studies which reported that the HDL level was significantly higher in the garlic administrated compared to the control group (Kwon et al., 2003). However, Christopher et al. (2001) showed that the garlic powder had no significant effect on plasma lipids levels. Also, supplementation with AGE (aged garlic extract) had no significant effects on serum total, LDL or HDL cholesterol and triglyceride concentration (Rahman \& Billington, 2000). The hypocholesterolemic effect of garlic oil may be related to the testosterone level in rabbits fed garlic diets, which indicates a higher turnover of cholesterol from blood to adrenal cortex for steroid synthesis. Thus, cholesterol was known as the precursor of all steroid hormones.

Table 4. Effect of garlic oil administration on plasma glucose and lipids profile NZW rabbits

\begin{tabular}{|c|c|c|c|c|c|c|c|c|c|c|c|}
\hline Treat. & Glucose & Chol. & TG & HDL & LDL & IgG & $\operatorname{IgM}$ & IgA & TAC & MDA & Testosterone \\
\hline & --------- & ------- & ------ & ----- mg & dl ----- & --.---. & ------. & ------- & \multicolumn{2}{|c|}{--- nmol/ml --- } & --- ng/ml --- \\
\hline $\mathrm{T} 1$ & $288.0^{\mathrm{a}}$ & 77.27 & 51.57 & $19.53^{\mathrm{b}}$ & 47.42 & $515.8^{\mathrm{ab}}$ & $133.0^{\mathrm{bc}}$ & $159.5^{\mathrm{b}}$ & $1.10^{\mathrm{b}}$ & $30.57^{\mathrm{a}}$ & $2.47^{\mathrm{c}}$ \\
\hline $\mathrm{T} 2$ & $268.7^{\mathrm{c}}$ & 71.50 & 54.03 & $19.97^{\mathrm{b}}$ & 40.73 & $522.4^{\mathrm{ab}}$ & $145.9^{\mathrm{ab}}$ & $178.9^{\mathrm{a}}$ & $1.25^{\mathrm{ab}}$ & $26.17^{\mathrm{bc}}$ & $3.64^{\mathrm{a}}$ \\
\hline $\mathrm{T} 3$ & $274.7^{\mathrm{bc}}$ & 74.87 & 47.43 & $23.03^{\mathrm{a}}$ & 42.35 & $570.4^{\mathrm{a}}$ & $159.3^{\mathrm{a}}$ & $192.9^{\mathrm{a}}$ & $1.39^{\mathrm{a}}$ & $24.83^{c}$ & $3.67^{\mathrm{a}}$ \\
\hline $\mathrm{T} 4$ & $278.3^{\mathrm{b}}$ & 74.43 & 50.03 & $19.10^{\mathrm{b}}$ & 45.33 & $506.4^{\mathrm{b}}$ & $128.1^{\mathrm{c}}$ & $150.7^{\mathrm{b}}$ & $1.18^{\mathrm{b}}$ & $28.73^{\mathrm{ab}}$ & $3.25^{\mathrm{b}}$ \\
\hline SEM & 2.5 & 3.94 & 3.20 & 0.86 & 3.01 & 17.1 & 5.08 & 5.64 & 0.05 & 0.92 & 0.09 \\
\hline Sig. & $* *$ & NS & NS & $*$ & NS & $*$ & $* *$ & $*$ & $*$ & $* *$ & $* * *$ \\
\hline
\end{tabular}

Note. a, b, c: Means in the same colum with different superscripts differ significantly $(\mathrm{P} \leq 0.05)$.

The results related for humoral immune response of rabbits showed significant increases in immunoglobulin in dose dependent minimum up to $0.50 \mathrm{~g} / \mathrm{kg}$ with highest concentration of immune response accrued at $0.5 \mathrm{~g} / \mathrm{kg}$ 
garlic oil diet. But, the high dose of garlic oil $0.75 \mathrm{~g} / \mathrm{kg}$ reduced the immunity response may be due to, that the over dose has toxic effect. These results are in agreement with previous studies which reported that supplementation of AGE in growing pigs can improve the immune response (Wang et al., 2011). Also, Alagawny et al. (2016) found that IgG increased by adding garlic powder until $6 \mathrm{~g} / \mathrm{kg}$ garlic powder to rabbits diet.

It is of great interest to notice that garlic oil administration to rabbits diet significantly increased TAC compared to the control group but, the best response was for rabbits fed $0.5 \mathrm{~g} / \mathrm{kg}$ garlic oil diet. Similarly, MDA was lower significantly by adding garlic oil. The present results support the previous researches concerning the rate of garlic as an antioxidant which was also evidenced in our study. These results are in agreement with other studies (Durak et al., 2002) which declared that garlic extract decreased the level of MDA in the blood samples which demonstrates reduced oxidation reactions in the body. In fact, the negative relation between MDA and HDL cholesterol indicates a synergetic effect of both parameters, where, HDL has a protective function in the prevention of a atherosclerosis while MDA fractions as a reliable indicator for oxidation reactions a long with the antioxidant capacity.

Results showed also an interesting observation concerning plasma testosterone concentrations in rabbits fed supplement garlic oil levels garlic oil where testosterone level was significantly higher for garlic oil treatments compared to the control group. This effect was due in part to, the significant higher in testes weights of growth performance rabbits as discussed before (Table 3). It is well known that testosterone Secretion is under the control of LH hormone via its effect on leydig cells. Since, Oi et al. (2001) suggested that garlic administration increases testosterone production in rat testis enhancement of LH secretion from the pituitary gland, which support our findings.

\subsection{Total Microbial Counts}

The populations of total bacterial count in the cecal contents especially coliform bacteria, were affected by garlic oil supplement to rabbit diets (Table 5). The results showed that the addition of garlic oil significantly decreased the count of coliform bacteria compared to the control treatments. However, garlic treatments significantly increased the total viable bacterial count. Garlic oil has shown much improved positive effects on growth performance and inhibition and controlling of pathogenic microorganism. The results showed that the lowest coliform bacteria counts were recorded to T3 followed by T2 treatments. It is likewise believed that garlic treatments increase the benefit bacteria in the large intestinal tract and improve the production of lactic acid and may provide an energy source of intestinal epithelial cell growth that improves nutrient absorption to definite level.

Table 5. Values of the viable total bacterial count (cfu/g) and specific microorganisms count found in cecal contents of rabbits fed Garlic oil supplemented diets

\begin{tabular}{lll}
\hline Treatments & Total count & Coliform bacteria count \\
\hline T1 & $239 \times 10^{4 \mathrm{~d}}$ & $91 \times 10^{\mathrm{a}}$ \\
T2 & $188 \times 10^{8 \mathrm{c}}$ & $5.4 \times 10^{\mathrm{b}}$ \\
T3 & $293 \times 10^{8 \mathrm{~b}}$ & $1.8 \times 10^{\mathrm{b}}$ \\
T4 & $830 \times 10^{8 \mathrm{a}}$ & $17.3 \times 10^{\mathrm{b}}$ \\
SEM & $17.5 \times 10^{8}$ & $6 \times 10$ \\
Sig. & $* * *$ & $* * *$ \\
\hline
\end{tabular}

Note. $\mathrm{a}, \mathrm{b}, \mathrm{c}, \mathrm{d}$ : Means in the same colum with different superscripts differ significantly $(\mathrm{P} \leq 0.05)$.

The antibacterial activities of garlic against $S$. typhi and harmful organisms were discussed by (Fleischauer \& Arab, 2001) to be related to the presence of several components such as alliin, alline, ajorene, diallyl sulfides, diallyl disulfides, diallyl trisulfides, S-allylcysteine, organosulfur compounds and allylsulfur compounds which make garlic as a powerful disease fighting agent. In earlier study (Jamroz et al., 2005) a significant reduction of coliform bacteria number has been obtained following an application of garlic treatments which exert a differential inhibition between beneficial intestinal microflora and potentially harmful enterobacteria (Rees et al., 1993). Also, Bokaeian and Bameri (2013) and Dangana et al. (2016) found that garlic has significantly antibacterial activity against coliform bacteria and effective on destroying enterococci.

From the previous findings, it is clear that the higher level of garlic was not effective in reducing the coliform bacterial count (T4) as the low levels. This holds true as immunoglobulin's level of this group T4 was 
significantly lower than the other groups indicative of an excellent defense mechanism creation. In this respect significant fractions of all immunoglobulin's bound to lactose-agarose are synthesized in the small intestine. By partial deposition in the brush border act as antibodies, which has protective function by preventing lectin-like pathogens from gaining access to the brush border surface. Hansen et al. (2006) in the small intestine, the host response toward pathogens relies upon antibodies to provide a first line of defense, and mainly secretory immunglobulin A, and to some extent secretory immunglobulin $\mathrm{M}$, produced by mucosal plasma cells in the lamina propria, accomplish this function. The antibodies are hereby delivered to the mucus layer of the gut to perform immune exclusion and clearance of antigens (Brandtzaeg \& Johansen, 2005; Hansen et al., 2006). The results of the blood plasma analysis agree with coliform bacterial count results, as the immunglobulin A levels were higher in the (T2 and T3) group then decrease in T4 group. The viable cells given to the T2 and T3 group probably acted like antigens that stimulate the IgA synthesis in the intestinal lymph tissue of rabbits. This effect may beneficial because the increase of immunglobulin $\mathrm{A}$ in the intestine decreased (prevents) growth pathogenic bacteria.

\section{Conclusion}

The finding of the present study indicate that supplemented of garlic oil at $0.5 \mathrm{~g} / \mathrm{kg}$ of diet has improved on HDL, immunoglobulin's G, antioxidant status and testosterone hormone in addition to its antibacterial effect.

\section{References}

Abd El-Azeem, F., \& Abd El-Reheem, M. A. T. (2006). Effect of supplemental copper and fresh garlic on performance and some biochemical changes in growing rabbits. Egypt. J. Rabbit Sci., 16(2), 341-366.

Adeniyi, B. A., Oluwole, F. S., \& Anyiam, F. M. (2006). Antimicrobial and Antiulcer Activities of Methanol Extract of Allium sativum on Helicobacter pylori. Journal of Biological Sciences, 6, 521-526. https://doi.org/10.3923/jbs.2006.521.526

Alagawany, M., Ashour, E. A., \& Reda, F. M. (2016). Effect of dietary supplementation of garlic (Allium sativum) and turmeric (Curcuma longa) on growth performance, carcass traits, blood profile and oxidative status in growing rabbits. Annals of Animal Science, 16(2), 1-17. https://doi.org/10.1515/aoas-2015-0079

Allain, C. C., Poon, L. S., Chan, C. S., Richmond, W. S., \& Fu, P. C. (1974). Enzymatic determination of total serum cholesterol. Clin. Chem., 20, 470-475.

Ankri, S., Mirelman, D., \& Sterling, S. J. (1999). Antimicrobial properties of allicin from garlic. Microbes Infect., 1, 125-129. https://doi.org/10.1016/S1286-4579(99)80003-3

Belemkar, S., Dhameliya, K., \& Pata, M. K. (2013). Comparative study of garlic species (Allium sativum and Allium porrum) on glucose uptake in diabetic rats. Journal of Taibah University Medical Sciences, 8(2), 80-85. http://dx.doi.org/10.1016/j.jtumed.2013.04.002

Bianchi, A. T., Moonen-Leusen, H. W., Van der Heijden, P. J., \& Bokhout, B. A. (1995). The use of a double antibody sandwich ELISA and monoclonal antibodies for the assessment of porcine IgM, IgG and IgA concentrations. Vet. Immunol.Immunopathol., 44, 309-317. https://doi.org/10.1016/0165-2427(94)05307-E

Bokaeian, M., \& Bameri, Z. (2013). In Vitro Antibacterial Properties of Aqueous Garlic Extract (AEG) Against Multidrug-Resistant Enterococci. Zahedan Journal of Research in Medical Sciences. ZJ RMS 2013; 15(6): 43-49.

Brandtzaeg, P., \& Johansen, F. E. (2005). Mucosal B cells: Phenotypic characteristics, transcriptional regulation, and homing properties. Immunol Rev, 206, 32-63. https://doi.org/10.1111/j.0105-2896.2005.00283.x

Chan, J. Y., Yuen, A. C., Chan, R. Y., \& Chan, S. W. (2013). A review of the cardiovascular benefits and antioxidant properties of allicin. Phytother Res, 27(5), 637-46. https://doi.org/10.1002/ptr.4796

Christopher, D. G., Chatterjee, M. L., \& Carlson, J. J. (2001). The effect of a garlic preparation on plasma lipid levels in moderately hypercholesterolemic adults. Atherosclerosis, 154, 213-220. https://doi.org/10.1016/ S0021-9150(00)00466-4

Corzo-Martinez, M., Corzo, N., \& Villamiel, M. (2007). Biological properties of onions and garlic. Trends in Food Science Technology, 18, 609-625. https://doi.org/10.1016/j.tifs.2007.07.011

Dangana, A. L., Nasi, I. A., \& Egenti, B. N. (2016). Preliminary evaluation of antibacterial potential of four common Nigerian plants against isolates of Staphylococcus aureus and Escherichia coli. N. Y. Sci. J., 9(6), 67-71. 
Demir, E., Kiline, K., \& Yildirim, Y. (2005). Use of antibiotic growth promoter and two herbal natural feed additives with and without exogenous enzymes in wheat base broiler diets. South Africa Anim. Sci., 35, 61-72.

Durak, I., Oztürk, H. S., Olcay, E., Can, B., \& Kavutcu, M. (2002). Effects of garlic extract on oxidant/antioxidant status and atherosclerotic plaque formation in rabbit aorta. Nutr Metab Cardiovasc Dis., 12(3), 141-7.

Fleischauer, A. T., \& Arab, L. (2001). Garlic and cancer: A critical review of the epidemiologic literature. J. Nutr., $131,1032 \mathrm{~S}-1040 \mathrm{~S}$.

Fossati, P., \& Prenciple, L. (1982). Serum triglycerides determined colorimetrically with an enzyme that produces hydrogen peroxide. Clin. Chem., 28, 2077-2080.

Friedewald, W. T., Levy, R. I., \& Fredrickson, D. S. (1972). Estimation of the concentration of low-density lipoprotein cholesterol in plasma, without use of the preparative ultracentrifuge. Clin Chem., 18, 499-502.

Hansen, G. H., Niels-Christiansen, L. L., Immerdal, L., \& Danielsen, E. M. (2006). Antibodies in the small intestine: Mucosal synthesis and deposition of anti-glycosyl $\operatorname{IgA}, \operatorname{IgM}$, and $\operatorname{IgG}$ in the enterocyte brush border. Am. J. Physiol. Gastrointest Liver Physiol., 291, G82-G90. https://doi.org/10.1152/ajpgi.00021.2006

Hossian, J. M. D., Kamruzzaman, M., Ali Akbar, Md., \& Ariful Haque, Md. (2015). Feeding garlic powder on growth performance, nutrient digestibility and carcass characteristics of rabbit. International Journal of Natural and Social Sciences, 2(5), 74-81.

Koracevic, D., Koracevic, G., \& Csic, V. (2001). Method for the measurement of antioxidant activity in human fluids. J. Clin. Pathol., 54(5), 356-364. http://dx.doi.org/10.1136/jcp.54.5.356

Kwon, M. J, Song, Y. S., Choi, M. S., Park, S. J., Jeong, K. S., \& Song, Y. O. (2003). Cholesteryl ester transfer protein activity and atherogenic parameters in rabbits supplemented with cholesterol and garlic powder. Life Sci., 72, 2953-64. https://doi.org/10.1016/S0024-3205(03)00234-0

Liu, C. T., Hse, H., Lii, C. K., Chen, P. S., \& Sheen, L. Y. (2005). Effects of Garlic Oil and Diallyl Trisulfide on Glycemic Control in Rats with Streptozotocin-Induced Diabetes. European Journal of Pharmacology, 516, 165-173. https://doi.org/10.1016/j.ejphar.2005.04.031

Merck. (1994). Microbiology manual E. Merck Darmstaadt, Bereich labor (D-64271). Darmstaadt, Germany.

Mihara, M. \& Uohiyama, M. (1978). Determination of malondialdehyde precursors in tissues by thiobarbituric acid test. Anal. Biochem., 86, 271-278. https://doi.org/10.1016/0003-2697(78)90342-1

Myers, G. L., Cooper, G. R., Henderson, L. O., Hassemer, D. J., \& Kimberly, M. (1994). Standardization of lipid and lipoprotein Measurements. In N. Rifai, \& G. R. Warnick (Eds.), Laboratory Measurement of Lipid and Lipoproteins and Apolipoproteins (pp. 177-205). AACC Press, Washington, DC, USA.

NRC. (1994). Metabolic Modifiers: Effects on the Nutrient Requirements of Food-Producing Animals. National Academy Press, Washington, DC.

Oi, Y., Imafuku, M., Shishido, C., Kominato, Y., Nishimura, S., \& Iwai, K. (2001). Garlic supplementation increases testicular testosterone and decreases plasma corticosterone in rats fed a high protein diet. J. Nutr., $131,2150-2156$.

Onibi, G. E., Adebisi, O. E., Fajemisin, A. N., \& Adetunji, A. V. (2009). Response of broiler chickens in terms of performance and meat quality to garlic (Allium sativum) supplementation. Afr. J. Agric. Res., 4, 511-517.

Prescott, L. M., Harley, J. P., \& Klein, D. A. (2005). Microbiology (6th ed., p. 992). Boston: McGraw-Hill.

Raeesi, M., Hoeini-Aliabad, S. A., Roofchaee, A., ZareShahneh, A., \& Pirali, S. (2010). Effect of periodically use of garlic (Allium sativum) power on performance and carcass characteristics in broiler chickens. World Academy of Science, Engineering and Technology, 68, 1213-1219.

Rahman, K., \& Billington, D. (2000). Dietary supplementation with aged garlic extract inhibits ADP-induced platelet aggregation in humans. J. Nutr., 130, 2662-2665.

Rana, S. V., Pal, R., Vaiphei, K., Sharma, S. K., \& Ola, R. P. (2011). Garlic in health and disease. Nutr. Res. Rev., 24(1), 60-71. https://doi.org/10.1017/S0954422410000338

Rees, L. P., Minney, S. F., Plummer, N. T., Slater, J. H., \& Skyrme, D. A. (1993). A quantitative assessment of the anti-microbial activity of garlic (Allium sativum). World J. Microbiol Biotechnol., 9, 303-307. https://doi.org/10.1007/BF00383068 
Roe, M. T., \& Pillai, S. D. (2003). Monitoring and identifying antibiotic resistance mechanisms in bacteria. Poultry Science, 82, 622-626. https://doi.org/10.1093/ps/82.4.622

Saleha, A. A., Miyang, T. T., Ganapathy, K. K., Zulkifli, I., Raha, R., \& Arifah, K. (2009). Possible effect of antibiotic-supplemented feed and environment on the occurrence of multiple antibiotic resistant $E$. coli in chickens. International Journal of Poultry Science, 8, 28-31. https://doi.org/10.3923/ijps.2009.28.31

Salih, J. M., Monawer, A. T., \& Abdullkahar, I. M. (2016). Antibacterial activity of garlic against multi-drug resistant staphylococcusaureus and enterococcus faecalis in duhok city. Journal of University of Duhok, 19(1), 114-122.

SAS. (2006). Statistical Analysis System, SAS User's Guide. Statistics SAS institute Inc., Cary, NC, USA.

Sasaki, J., Kita, T., Ishita, K., Uchisawa, H., \& Matsue, H. (1999). Antibacterial activity of garlic powder against Escherichia coli O-157. J. Nutr. Sci. Vitaminol., 45, 785-790. https://doi.org/10.3177/jnsv.45.785

Sharp, P. J., Culbert, J., \& Wells, J. W. (1977). Variations in stored and plasma concentrations of androgens and luteinizing hormone during sexual development in cockerel. J. Endocrinol., 74, 467-472. https://doi.org/ 10.1677/joe.0.0740467

Wang, J. P., Yoo, J. S., Jang, H. D., Lee, J. H., Cho, J. H., \& Kim, I. H. (2011). Effect of dietary fermented garlic by Weissella koreensis powder on growth performance, blood characteristics, and immune response of growing pigs challenged with Escherichia coli lipopolysaccharide. J. Anim. Sci., 89, 2123-2131. https://doi.org/10.2527/jas.2010-3186

Ziarlarimi, A., Irani, M., Gharahveysi, S., \& Rahmani, Z. (2011). Investigation of antibacterial effects of garlic (Allium sativum), mint (Menthe spp.) and onion (Allium cepa) herbal extracts on Escherichia coli isolated from broiler chickens. African Journal of Biotechnology, 10(50), 10320-10322. https://doi.org/10.5897/ AJB10.2513

\section{Copyrights}

Copyright for this article is retained by the author(s), with first publication rights granted to the journal.

This is an open-access article distributed under the terms and conditions of the Creative Commons Attribution license (http://creativecommons.org/licenses/by/4.0/). 